\title{
FLORIDA STATE UNIVERSITY RADIOCARBON DATES IV
}

\section{S. J. DAUGHERTY, J. R. MARTIN,* and D. S. PHELPS**}

Radiocarbon Dating Laboratory, Department of Geology

The Florida State University, Tallahassee, Florida 32306

This list includes mainly the results of datings done from 1967 to 1969. Methods are essentially the same as those described in Radiocarbon, 1966 , v. 8 , p. $46-53$, 1967 , v. 9 , p. $38-42$, and 1969 , v. 11, p. 15-21. Samples synthesized to benzene and counted by liquid scintillation spectrometry. Age calculations are based on $95 \%$ of the activity of the NBS oxalic acid standard and computed from the Libby half-life of $5570 \mathrm{yr}$ and reference A.D. 1950. The error listed is the one-sigma statistical counting error. Most samples were counted for 2000 to $3000 \mathrm{~min}$. HCL and $\mathrm{NaOH}$ pretreatments were applied to samples as required.

In January 1969, a Picker Nuclear Liquimat 220 was purchased to replace the ANS, Inc. spectrometer. Initial performance was excellent, with an $\mathrm{E}^{2} / \mathrm{B}$ of ca. 1000 (efficiency $60-65 \%$ ) and a background of ca. $4 \mathrm{cpm}$. However, trouble with the electronics and photomultiplier tubes resulted in the counter being inoperable for 11 of the 12 months prior to March 1970. This counter is now in excellent working order with an $\mathrm{E}^{2} / \mathrm{B}$ of 800 (efficiency $65 \%$ ) and a background of $5.4 \mathrm{cpm}$.

\section{SAMPLE DESCRIPTIONS}

I. GEOLOGIC SAMPLES

\section{Leon Florida series}

Soil and wood coll. and subm. 1967 by C. L. Coultas, Florida A \& M Univ.

FSU-249. Shell Point

$$
1760 \pm 60
$$

Bh horizon soil $\left(30^{\circ} 6^{\prime} 0^{\prime \prime} \mathrm{N}\right.$ Lat, $84^{\circ} 18^{\prime} 0^{\prime \prime} \mathrm{W}$ Long), from 42 to $52 \mathrm{~cm}$ below ground surface $\left(\mathrm{pH} 4.45,1: 1 \mathrm{H}_{2} \mathrm{O}\right)$. Coll. at junction of State Rds. 367 and 367a in St. Mark's Nat. Wildlife Refuge.

\section{FSU-250. St. Mark's Lighthouse}

$6020 \pm 300$

Bh Horizon soil $\left(30^{\circ} 5^{\prime} \mathrm{N}\right.$ Lat, $84^{\circ} 10^{\prime} \mathrm{W}$ Long), from 56 to 72 $\mathrm{cm}$ below ground surface $\left(\mathrm{pH} 5.9,1: 1 \mathrm{H}_{2} \mathrm{O}\right)$ from salt marsh ca. 11/4 mi NE of lighthouse.

\section{FSU-251. Port Leon-1}

Sandy peat $\left(30^{\circ} 7^{\prime} 30^{\prime \prime} \mathrm{N}\right.$ Lat, $84^{\circ} 12^{\prime} \mathrm{W}$ Long), 119 to $145 \mathrm{~cm}$ below ground surface in Juncus salt marsh along St. Mark's R.

* Present address: Cape Fear Technical Institute, Wilmington, North Carolina

** Present address: East Carolina University, Greenville, North Carolina 
FSU-252. Port Leon-2

Wood found in sandy peat $\left(30^{\circ} 7^{\prime} 30^{\prime \prime} \mathrm{N}\right.$ Lat, $84^{\circ} 12^{\prime} \mathrm{W}$ Long), 145 to $175 \mathrm{~cm}$ below ground surface in Juncus salt marsh along St. Mark's R.

General Comment (C.L.C.): FSU-249 and 250 are from an apparent organic pan formed under a leached $\mathrm{A}_{2}$ horizon. These dates indicate that it took ca. $3000 \mathrm{yr}$ to build up ca. $120 \mathrm{~cm}$ of soil in this area. FSU250 seems much too old.

\section{Carrabelle Beach series}

Coll. and subm. 1967 by G. H. Dury, Univ. of Wisconsin.

FSU.192. Carrabelle Beach-1

Peat (295 $50^{\prime} 07^{\prime \prime}$ N Lat, $84^{\circ} 41^{\prime} 30^{\prime \prime}$ W Long).

$405 \pm 155$

FSU-193. Alligator Point

A.D. 1545

Peat (29 $53^{\prime} 37^{\prime \prime} \mathrm{N}$ Lat, $84^{\circ} 22^{\prime} 30^{\prime \prime} \mathrm{W}$ Long), from intertidal zone on seaward face of spit.

FSU-194. Carrabelle Beach-2

$940 \pm 80$

Wood (29 $50^{\prime} 07^{\prime \prime} \mathrm{N}$ Lat, $84^{\circ} 41^{\prime} 30^{\prime \prime}$ W Long), from dead tree bole in intertidal zone, surrounded by peat from which FSU-192 was taken.

FSU-195. Carrabelle Beach-3

$6340 \pm 160$

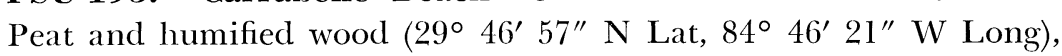
from intertidal zone at base of a low cliff. Comment (G.H.D.): peat and wood, dated separately, gave similar results. Both relate to a former swamp forest buried by dune sediments; present exposure indicates retrogradation in progress.

General Comment (G.H.D.): general evidence of retrogradation might be relevant to development of Crooked R., a double-ended tidal creek which is under geomorphic study. FSU-192 and FSU-194 indicate presence of swamp forest ca. $950 \mathrm{yr}$ ago, swamp growth continuing until less than $200 \mathrm{yr}$ ago, and subsequent retreat of shoreline.

\section{ARCHAEOLOGIC SAMPLES}

\section{Borklund Mound, Florida}

The site (8Ta35) is located approx. $15 \mathrm{mi} \mathrm{SW}$ of Perry, Florida, and $1 \mathrm{mi}$ inland from Gulf of Mexico between the Enconfina and Fenholloway Rivers $\left(30^{\circ} 02^{\prime} 0^{\prime \prime} \mathrm{N}\right.$ Lat, $83^{\circ} 55^{\prime} 10^{\prime \prime} \mathrm{W}$ Long). Excavated by amateurs, the mound contained ceramics and burials of both early and late Swift Creek phase, and appears to have been in continuous use. Coll. and subm. 1965 by D. S. Phelps, Florida State Univ. 
FSU-78. Borklund

Charred wood from mound fill $62 \mathrm{~cm}$ above base. Comment: date serves only as possible point along continuum of mound use; no relation to specific deposit within mound.

\section{Nichols site series}

The Nichols site near Panacea, Wakulla Co., Florida $\left(29^{\circ} 59^{\prime} 45^{\prime \prime}\right.$ $\mathrm{N}$ Lat, $84^{\circ} 25^{\prime} 41^{\prime \prime} \mathrm{W}$ Long) encompasses a large midden (8Wa3), a $33 \mathrm{~m}$ diam. platform mound (Mound A, 8Wa35), and 2 destroyed mounds (8Wa53, 55) of unknown purpose. Primary occupation of the midden and construction of mounds was accomplished during Weeden Island phase. A later Fort Walton phase occupation of site was insignificant, but platform mound was used as a burial area by this component. Moore (1902) excavated parts of Mound A, and Willey (1949) coll. ceramics from midden during his survey. The intrusive Fort Walton burials caused Willey to state that the platform mound may have been a Fort Walton structure, an hypothesis negated by Florida State Univ. excavations in 1955 and 1966. Coll. and subm. 1964 by D. S. Phelps.

\section{FSU-153. Nichols Mound A 1}

$$
1550 \pm 65
$$

Shell (Rangia cuneata) from fill of 2nd construction stage of mound, assoc. with Weeded Island ceramics. Comment: both this date and FSU155 , below, can only provide limit for earliest mound construction, not to be interpreted as dating the actual event.

\section{FSU-155. Nichols midden 1}

Charred wood from fill of Feature 2, a Weeden Island refuse pit remaining intact in midden area. Assoc. with late Weeden Island ceramics and $1 / 4$ of Wakulla Check Stamped vessel. Comment: dates late Weeden Island component of site.

FSU-155. Nichols midden A 2

$1550 \pm 55$

Shell (Rangia cuneata) from fill of 1 st mound construction stage.

\section{Stoutamire Site series, Florida}

The Stoutamire site (8Le107) is in Leon Co., Florida, on Ochlockonee R. (30 $41^{\prime} 32^{\prime \prime} \mathrm{N}$ Lat, $84^{\circ} 20^{\prime} 30^{\prime \prime}$ W Long). Excavated by Florida State Univ. in 1966, it contained 2 distinct components separated by a sterile sand deposit. Earliest component, Norwood, was represented by fiber-tempered sherds and steatite vessel fragments. The following dates pertain to the Weeden Island component, a small shell and refuse midden containing typical Weeden Island ceramics, including small, but equal quantities of Swift Creek Complicated Stamped II and Wakulla Check Stamped. Coll. and subm. 1966 by D. S. Phelps. 
FSU-166. Stoutamire 2

Charred wood from Pit 1, Sq. 30R40, Level 1.

FSU-167. Stoutamire 1

Charred wood from Pit 1, 30R30, Level 1.
$1285 \pm 50$

A.D. 665

$1415 \pm 55$

A.D. 535

General Comment: both dates apply to early Weeden Island phase.

\section{Maltby site, Florida}

Located on S shore of Santa Rosa Sound in Okaloosa Co., Florida $\left(33^{\circ} 62^{\prime} 35^{\prime \prime} \mathrm{N}\right.$ Lat, $85^{\circ} 40^{\prime} 30^{\prime \prime} \mathrm{W}$ Long). Maltby site (80k31c) is a shell midden occupied from Deptford through Fort Walton phases; Weeden Island phase is sparsely represented. Sample coll. and subm. by Y. W. Lazarus.

\section{FSU-181. Maltby site $\mathrm{C}$}

Charcoal from Pit 65-2, 24 in. level, in W extremity of site. Comment: date probably applies to early Fort Walton component.

\section{Zabski site, Florida}

Located near extreme $\mathrm{S}$ end of Merritt I., Brevard Co., Florida $\left(28^{\circ}\right.$ $09^{\prime} 20^{\prime \prime} \mathrm{N}$ Lat, $80^{\circ} 36^{\prime} 30^{\prime \prime} \mathrm{W}$ Long). Zabski site (8Br165) is the 1st site in E Florida to yield a date for St. Johns I ceramics. This part of site was occupied during what Bullen (1959) termed the "Transitional Period." Coll. 1966 by S. Atkins and subm. by R. P. Bullen, Florida State Mus.

FSU-200. Zabski site, FSM 1

$2910 \pm 80$

Charcoal combined from Levels 4-6 (6 in each) of test pit in midden. Comment: sample assoc. with St. Johns I ceramics; mixed level sample should be used with caution.

\section{Caxambus site, Florida}

This site is located in Collier Co., Florida (25 $54^{\prime} 56^{\prime \prime} \mathrm{N}$ Lat, $81^{\circ}$ $42^{\prime} 55^{\prime \prime} \mathrm{W}$ Long). Assoc. ceramic sample was an undecorated, sandtempered pottery throughout $140 \mathrm{~cm}$ of excavated midden. Coll. and subm. 1967 by L. R. Morrell, Florida Bur. of Historic Sites and Properties.

\section{FSU-229. Caxambus 1}

$1670 \pm 135$

Charred wood from Sq. H, Level 7 (120 to $140 \mathrm{~cm}$ below surface), assoc. with a support post for an elevated Glades I residence structure. Comment: 1st radiocarbon date for Glades I phase in region.

\section{Third Gulf Breeze Site series, Florida}

The Third Gulf Breeze site (8Sa8), one of a series of middens along S shore of Santa Rosa Sound, located immediately E of town limits of Gulf Breeze, Florida (30²2' $0^{\prime \prime} \mathrm{N}$ Lat, $87^{\circ} 08^{\prime} 30^{\prime \prime} \mathrm{W}$ Long). Excavations 
by Willey (1949, p. 89-94) established primary occupation in Santa RosaSwift Creek phase with a later occupation of site in Fort Walton phase. Later excavations (Phelps, 1969) refined Santa Rosa-Swift Creek context. Samples coll. and subm. 1969 by D. S. Phelps.

FSU-350. Third Gulf Breeze 2

Charred wood from Zone II, Level 2, Sq. E.

FSU-351. Third Gulf Breeze 3

Charred wood from Feature 1, Sq. E; a hearth filled with burned Coquina shell, ash, and charcoal.

General Comment: both dates seem late for Santa Rosa-Swift Creek, but FSU-350 may be proper for late segment of the continuum; some intrusive material may have been derived from overlying Fort Walton component.

\section{Town Creek Mound series, North Carolina}

A series of 3 more dates for various construction stages of Town Creek Mound (Mg2), Montgomery Co., North Carolina (35 40 $30^{\prime \prime}$ $\mathrm{N}$ Lat, $75^{\circ} 59^{\prime} 0^{\prime \prime} \mathrm{W}$ Long). This platform mound is assigned to the Pee Dee phase (Coe, 1952); ceramic complex from site was recently described by Reid (1965). Subm. 1958 by J. L. Coe, Univ. of North Carolina.

\section{FSU-184. Town Creek 3}

\section{A.D. 1205}

$745 \pm 140$

Charred wood of post fragment from pre-mound humus in Sq. 60R30, Level A. Sample coll. 1940. Comment: sample from area beneath center of mound, ruling out later intrusive contaminants.

\section{FSU-185. Town Creek 4}

$\mathbf{5 9 5} \pm \mathbf{5 0}$

Charred wood from Wall Post 106, Temple 1 on summit of 1 st mound stage. Sample coll. 1948. Comment: compares favorably with earlier date of pre-mound level (FSU-184, above).

FSU-186. Town Creek 5

$670 \pm 40$

Charred fragments of wood from Wall Post 1, Temple 2 on summit of mound. Charred post was buried by a collapsed clay wall. Comment: date is earlier than FSU-185 but a later construction date for this structure is justified within the 2-sigma range of this date. A previous sample from another post of this structure dated A.D. 1350 (FSU-154, $600 \pm$ 140; Knauer et al., 1967).

\section{Quelepa series, El Salvador}

Charcoal from Quelepa site, San Miguel Prov., El Salvador $\left(13^{\circ}\right.$ $31^{\prime} \mathrm{N}$ Lat, $88^{\circ} 15^{\prime} \mathrm{W}$ Long). Coll. 1968 and subm. by E. W. Andrews $\mathrm{V}$, Tulane Univ. 


$\begin{array}{lllc}\text { FSU-337. } & \text { Quelepa } & \text { Cache 6 } & 2020 \pm 55 \\ & & & 70 \text { B.c. } \\ \text { FSU-338. } & \text { Quelepa } & \text { Cache } 7 & 2055 \pm 65 \\ & & & 105 \text { B.c. } \\ \text { FSU-353. } & \text { Quelepa } & \text { Cache } 13 & 1460 \pm 90 \\ & & & \text { A.D. } 490 \\ \text { FSU-354. } & \text { Quelepa } & \text { Structure } 4 & 1285 \pm 70 \\ & & & \text { A.D. } 665 \\ \text { FSU-366. } & \text { Quelepa } & \text { Structure } 23 & 2100 \pm 75 \\ & & 150 \text { B.c. } \\ \text { FSU-367. } & \text { Quelepa } & \text { Structure } 29 & 1540 \pm 60\end{array}$

General Comment (E.W.A.): Quelepa is largest and perhaps most important site in E El Salvador. FSU-337 and FSU-338 provide dates for Late Preclassic in El Salvador, which correspond closely to Miraflores phase in Maya Guatemala Highlands. FSU-353 and FSU-354 are the only $\mathrm{C}^{14}$ dates on Early Classic architecture in El Salvador and date burning of an Early Classic structure.

\section{Spirit Cave series, Thailand}

Wood charcoal from Spirit Cave, Maehongson Prov., N Thailand (19 $34^{\prime} \mathrm{N}$ Lat, $98^{\circ} 7^{\prime} \mathrm{E}$ Long). Coll. 1966 and subm. by Chester Gorman, Univ. of Hawaii.

\begin{tabular}{|c|c|c|c|c|}
\hline FSU-314. & Spirit & Cave & Layer 2 & $\begin{array}{l}7905 \pm 195 \\
5955 \text { в.с. }\end{array}$ \\
\hline FSU-315. & Spirit & Cave & Layer 3 & $\begin{array}{c}11,350 \pm 280 \\
9400 \text { в.C. }\end{array}$ \\
\hline FSU-316. & Spirit & Cave & Layer 5 & $\begin{array}{c}10,900 \pm 550 \\
8950 \text { в.с. }\end{array}$ \\
\hline FSU-317. & Spirit & Cave & Layer 2 & $\begin{array}{l}7400 \pm 150 \\
5450 \text { в.C. }\end{array}$ \\
\hline FSU-318. & Spirit & Cave & Layer $2 \mathbf{a}$ & $\begin{array}{l}8520 \pm 145 \\
6570 \text { в.C. }\end{array}$ \\
\hline
\end{tabular}

General Comment (C.G.): recent excavation in Spirit Cave and assoc. $\mathrm{C}^{14}$ dates provided evidence for early (ca. 7000 B.C.) domestication of plants in SE Asia (Gorman, 1969). FSU-314 and FSU-318 date upper portion of deposit and agree well with other determinations (TF-802 and GAK-1846). FSU-315 and FSU-316 are thus far the earliest dates for mainland SE Asia. FSU-317 dates top of Spirit Cave sequence. These dates generally bracket Pleistocene/Recent boundary in SE Asia and show it to be of little significance. General conclusion concerning the $\mathrm{C}^{14}$ and cultural sequence will appear in Asian Perspectives, v. 11 (in press). 
Non Nok Tha series, Thailand

Samples from Non Nok Tha site, Khon Kaen Prov., NE Thailand (16 $6^{\circ} 47^{\prime} 57^{\prime \prime} \mathrm{N}$ Lat, $102^{\circ} 18^{\prime} 17^{\prime \prime} \mathrm{E}$ Long). Coll. 1968 and subm. by D. T. Bayard, Univ. of Hawaii.

FSU-339. Non Nok Tha Layer 5
Bamboo charcoal from Sq. 3e/3f, Level 8.

FSU-340. Non Nok Tha Layer $11 \quad$ 2485 B.c.

Carbonized wood containing considerable termite frass from Sq. $4 \mathrm{~g}$.

\section{FSU-341. Non Nok Tha}

Layer 7

$\mathbf{2 4 7 0} \pm \mathbf{7 0}$

Charcoal fragments from Sq. 4f.

Charcoal from Sq. 1e.

$\begin{array}{llr}\text { FSU-343. Non Nok Tha } & \text { Layer 4 } & \text { Modern } \\ \text { Charcoal from Sq. 1e. } & & \mathbf{3 5 6 0} \pm \mathbf{6 5} \\ \text { FSU-345. Non Nok Tha } & \text { Mound } 125 & \mathbf{1 6 1 0} \text { в.c. }\end{array}$

Charcoal from Sq. 3e.

General Comment (D.T.B.): these dates are relevant to early development of metallurgy in SE Asia (see Solheim, 1968). Conclusions concerning these and other dates will appear in Asian Perspectives, v. 11 (in press). Most dates from this site support presence of metallurgy by ca. 3500 B.C., and of a fairly complex bronze technology prior to 2300 B.c. Above dates, however, tend to support simultaneous arrival of iron and bronze between 800 and 300 B.c. Samples possibly were contaminated either naturally or in shipment, although no source of contamination is apparent.

\section{REFERENCES}

Bullen, R. P., 1959, The Transitional Period of Florida: Southeastern Arch. Conf. Newslctter, v. 6, p. 43-62.

Coe, J. L., 1952, Culture Sequence of the Carolina Piedmont, in: Archeology of Eastern United States, J. B. Griffin, (ed.) p. 301-311: Chicago, Univ. of Chicago Press, 392 p.

Gorman, C. F., 1969, Hoabinhian: A Pebble-tool complex with early plant associations in Southeast Asia: Science, v. 163, p. 671-673.

Knauer, G. A., Martin, J. R., Goodell, H. G., and Phelps, D. S., 1967, Florida State University radiocarbon dates: Radiocarbon, v. 9, p. 38-42.

Moore, C. B., 1902, Certain Aboriginal remains of the Northwest Florida coast, pt. 2: Acad. Nat. Sci. Jour., Philadelphia, v. 12, p. 281-282.

Phelps, D. S., 1969, Swift Creek and Santa Rosa in Northwest Florida: Univ. of South Carolina Inst. of Arch. and Anthropol. Notebook, v. 1, nos. 6-9, p. 14-24.

Reid, J. J., 1965, A comparative statement on ceramics from the Hollywood and the Town Creek Mounds: Southern Indian Studies, v. XVII, p. 12-25.

Solheim, W. G., 1968, Early Bronze from Northeastern Thailand: Current Anthropology, v. 9, no. 1, p. 59-62.

Willey, G. R., 1949, Archeology of the Florida Gulf Coast: Smithsonian Misc. Coll., v. 113 , p. 599. 